\title{
Vehicular Analysis of a Bridge Structure Considering IRC Loading Condition using Sap 2000
}

\author{
Nikhil Kumar Singh \\ M.Tech. Scholar \\ Sarvepalli Radhakrishnan University \\ Bhopal, Madhya Pradesh, India \\ alphanick98@gmail.com
}

\author{
Jyoti Yadav \\ Assistant Professor \\ Sarvepalli Radhakrishnan University \\ Bhopal, Madhya Pradesh, India \\ jyoti.y2308@gmail.com
}

\begin{abstract}
A beam bridge is a bridge that uses struts as a method of supporting the deck. A bridge consists of three sections: the foundation consisting of protrusions and supports and the substructure consisting of protrusions and quay and the superstructure (bracing, cantilever or curve) and the deck. A beam bridge is probably the most manufactured and used bridge on the planet. Its basic plant, at its best, can be likened to a tree trunk extending to one side to alternate across a stream or river. All decks consist of two main parts: the substructure and the superstructure. The superstructure is everything from the support cushions to - it's the thing that supports the posts and it's the most distinctive part of the deck. The substructure is the device that exchanges the poles of the superstructure on the ground. The two sections must work together to form a strong and durable bridge. Prestressed concrete is basically concrete where the internal concern is reasonable and the pressure propagation created by the external load is concentrated to the desired extent. In this research, we analyze a beam bridge with the effect of prestressed concrete and compare it to a generic deck bridge. Regarding the finite element analysis, the analysis of forces and costs. Here it is concluded that the implementation of a prestressed ceiling results in an economical, stable and load-resistant element.
\end{abstract}

Keywords: Structural Analysis, SAP2000, Pre-tensioning, Foam Concrete, Deck, Bridge, Vehicular load.

\section{INTRODUCTION}

A girder bridge is a bridge that uses struts as a method of supporting the deck. A bridge consists of three sections: basin overhang and foundation, overhang and dock substructure, superstructure (bracing, cantilever or curve) and deck. A beam bridge is probably the most commonly manufactured and used bridge on the planet. Its basic plant, at its best, can be likened to a tree trunk extending to one side to alternate across a stream or river. All decks consist of two main parts: the substructure and the superstructure. The superstructure is everything from the support cushions to - it's the thing that supports the poles and it's the most distinctive part

www.ijoscience.com of the deck. The substructure is the device that exchanges the poles of the superstructure on the ground. The two sections must work together to form a strong and durable bridge. Prestressed concrete is essentially concrete in which the internal concerns are sufficiently concentrated and the expansion pressure due to external stresses is concentrated to the desired extent.

\section{LITERATURE REVIEW}

Gaurav Somani et al. [1] Concrete slabs and T-pillar bridges are the prevailing bridges in India. Lately, specifically, a ton of street works have been in progress, some are under development and some street projects are anticipated what's to come. As the undertaking develops, it is important to further develop the plan technique consistently and make it more effective.

K. Hemalatha et al. [2] A bridge is a design that permits you to cross a hindrance without shutting the way underneath. The necessary crossing point can be a street, a rail line, a passerby, a waterway or a line. There are many sorts of areas for bridge development, among which bridges with T-pillars and box radiates have been chosen. T-pillar bridges are projected set up concrete bridges, famous for limited abilities to focus cheap. Additionally, the summed up caisson bridge was picked, which is practical for huge ranges, which can be single-stage or multistage radiates. In the current examination, a two path single help RCC-T pillar and a prestressed concrete box bar bridge for dead burden and moving burdens IRC were dissected and planned, the moving burden viewed as the class AA caterpillar vehicle. Courbon's technique for investigation and plan. Dead burden and payload estimations were performed physically.

Meghana K V et al. [3] A bridge is a construction worked over a street, stream, or railroad track to make it simpler for individuals and vehicles to cross from one side to the next. Determination of the most reasonable segment in bridges of various ranges, similar investigations are completed. The 
principle objective of the work is to consider the impacts of Tbars and box bridges of various ranges under moving burdens utilizing programming and manual strategies.

Manohar $\mathrm{R}$ et al. [4] T-beam deck section bridges are the essential sort of cast set up concrete bridges and comprise of fundamental pillars, cross bars that confer parallel firmness to the deck chunk, and a cover piece that sits set up. 'expands consistently between the T-radiates

There are numerous techniques that have been utilized for the examination of bridges with T-radiates, these are traditional strategies like the Courbon strategy, the Guyon-Massonet technique, the Hendry strategy Jaegar for radiates and the Pigeaud coefficient strategy for cover plates and limited components. The strategy is an overall technique for primary investigation which is drawn closer by examining a bunch of limited components which are associated together in a limited number of hubs and which address the arrangement space of the issue.

\section{OBJECTIVES}

- Study of existing design of Deck Bridge.

- Study of bridge design using SAP 2000 based on F.E.M.

- Study on suitability of different materials for bridge design.

- Techno economic analysis of materials selected for bridge constructs.

\section{Methodology}

\subsection{General}

In this research work our motive is to justify the variation in strength and cost of four cases of bridges for same loading and hydraulic conditions to carry out the best of them.

In this study, I am focusing the analysis using finite element method using analysis tool SAP 2000, which is capable of applying all conditions and methods with respect to preferred standard code.

\subsection{Methodology}

Following steps are required in a sequence for proper completion:
Step-1 Determine the site condition and position for casting bridge.

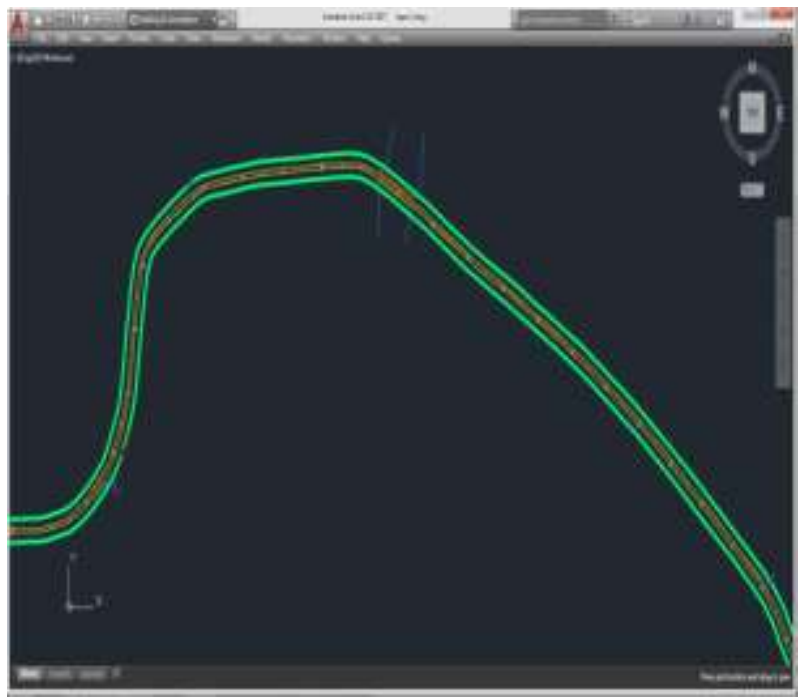

Fig 1: Road Plan

Step-2 Hydraulic design to determine required Bridge length and profile grade.

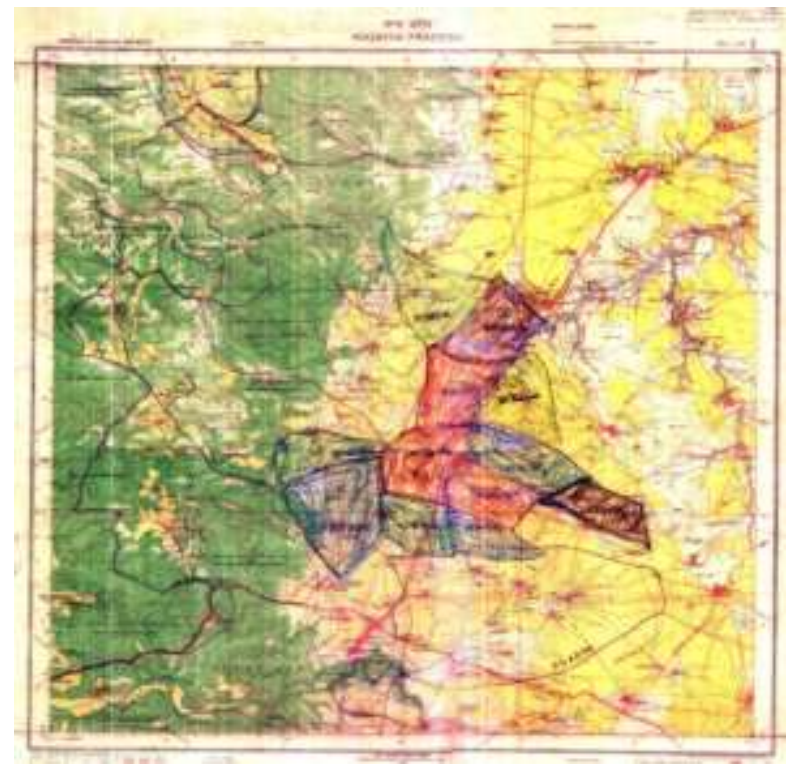

Fig 2: Topography Sheet of Proposed Site

Step-3 Preparation of geometry of Bridge in SAP 2000 


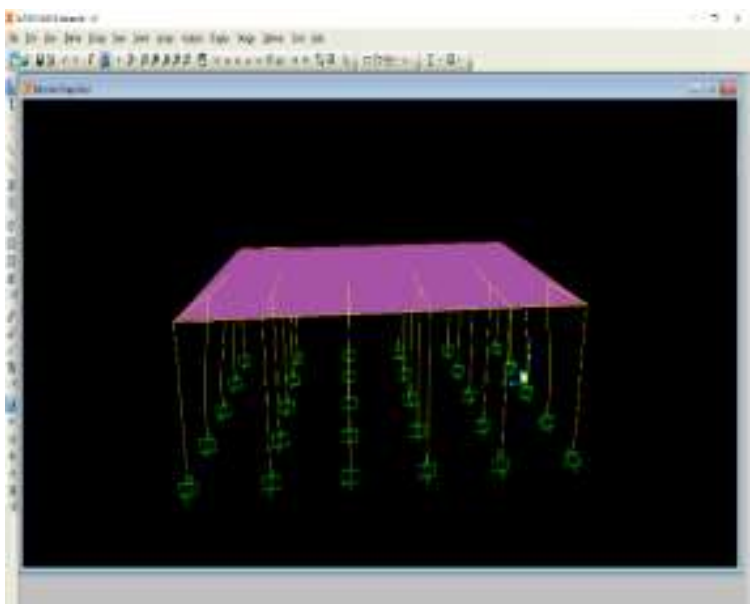

Fig 3: Pre-stressed Deck Modeling

Step-4 Assigning of Loads and section properties with support conditions.

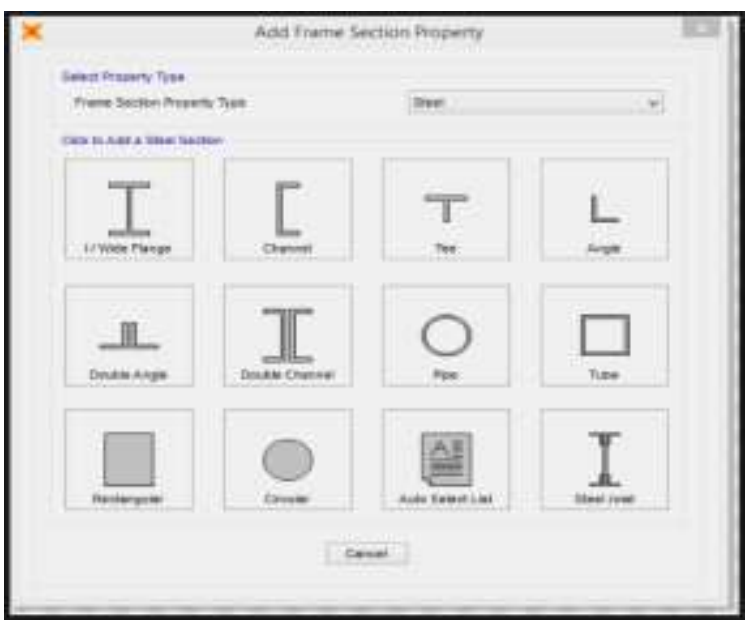

Fig 4: Sectional Properties

Step-5 Assigning hydraulic load and vehicle load as per I.R.C.

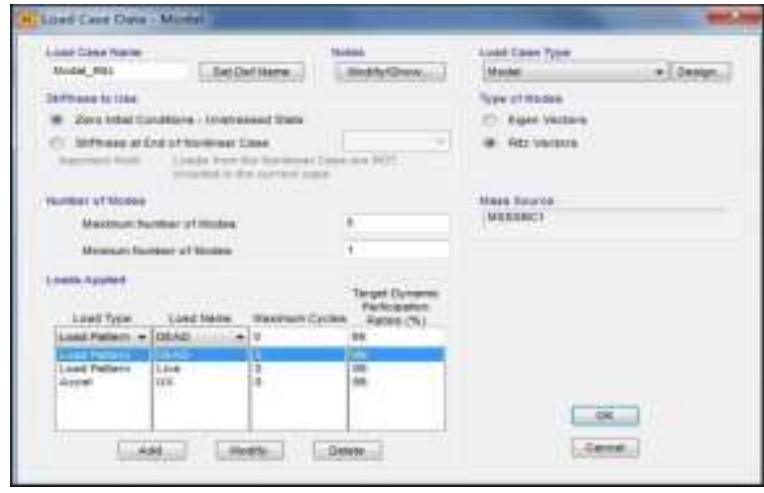

Fig 5: Load Cases

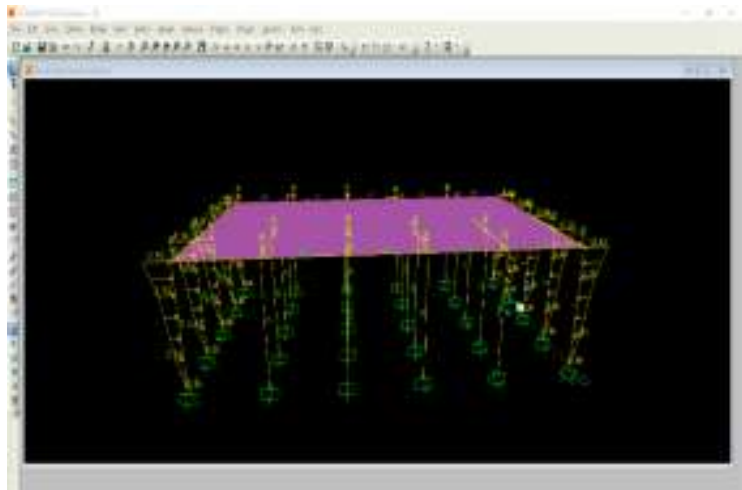

Fig 6: Finite Element Analysis on bridge

Step-7 Assigning Pre-stressed deck

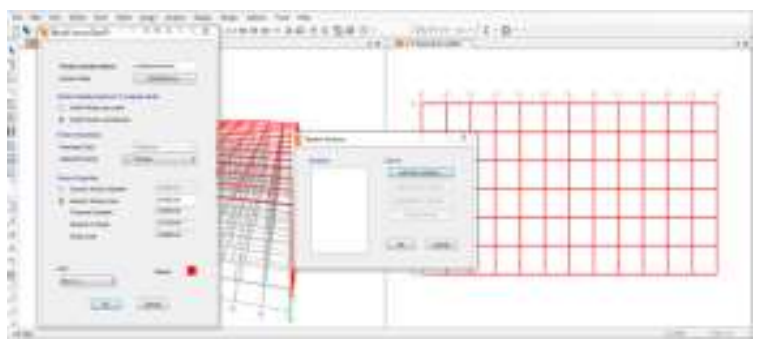

Fig 7 Assigning Pre-stressed deck

4.3 Methodology of this research and analysis is shown with the help of flowchart of Activities in figure 8

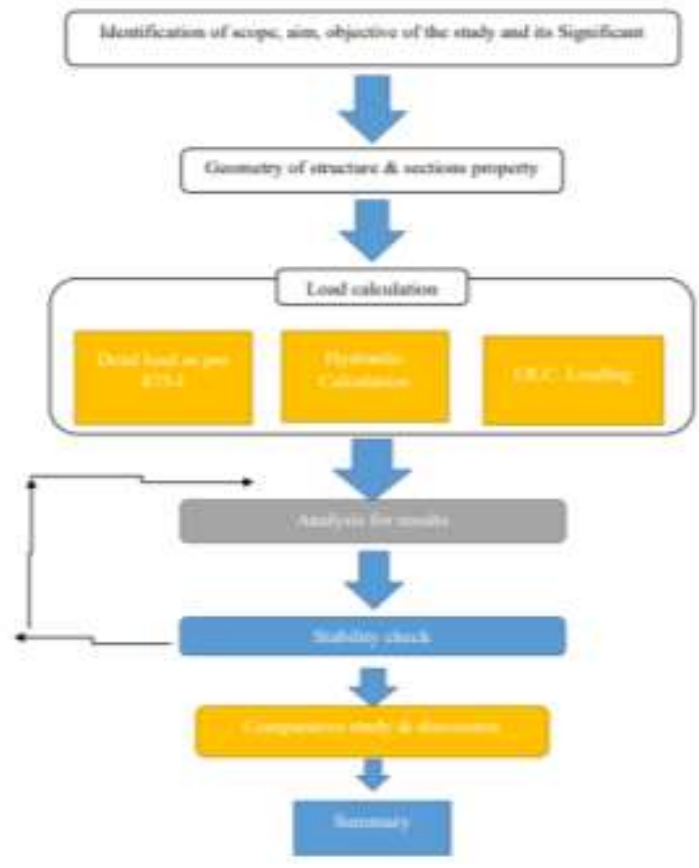

Fig: 8 Flow Chart of Activities

Step-6 Analysis (finite element) 


\subsection{Problem statement}

This chapter deals with loading calculation of the critical load placing over the considered culverts applying I.R.C. loading and hydraulic calculation using finite element method.

In this research work, we have used SAP-2000 software which is based on the application of Finite Element Method. This software is a widely used in the field of structural design and analysis. Now a day this software is very much friendly for the analysis of different type of structures and to calculate the result at every node \&element wise. Analysis for the bridge, prepared the conceptual dimension geometry of the superstructure which are shown in figure $9-$

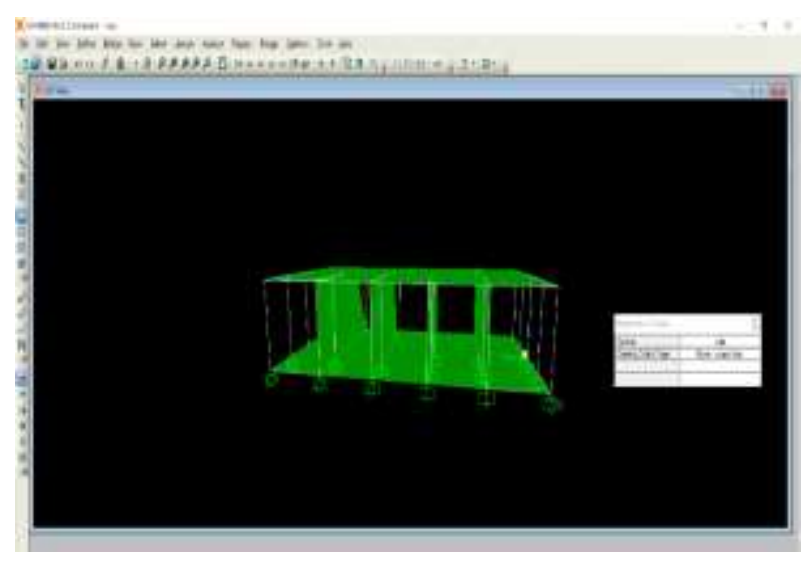

Fig: 9 Structural Modelling

Here bridge frame is modeled using analysis tool SAP-2000 in which vehicle load is applied. Than it is analyzed and optimized and I.R.C. loading is considered as class A vehicle loading, dead load as per 875 part-1 and superimposed live load as per 875 part- 2 is calculated and applied.

\subsubsection{Hydraulic calculation}

In the table 1 below details of hydraulic data and constants are described briefly:

Table 1: Hydraulic calculation

\begin{tabular}{|l|c|}
\hline \multicolumn{2}{|l|}{ (A) Dickens formula to calculate Peak Run-off from Catchment: } \\
\hline Area of Catchment (A): & $1524.6 \mathrm{Ha}$ \\
\hline Dickens Constant, $C_{D}$ (for Central India): & 16 \\
\hline Discharge $=C_{D} \times(A)^{3 / 4}$ & 123.45 \\
& $\mathrm{~m}^{3} / \mathrm{s}$ \\
\hline Discharge Through the Stream & $124 \mathrm{~m}^{3} / \mathrm{s}$ \\
\hline Regime width $=4.8 \times(\mathrm{Q})^{0.5}$ & $53.45 \mathrm{~m}$ \\
\hline
\end{tabular}

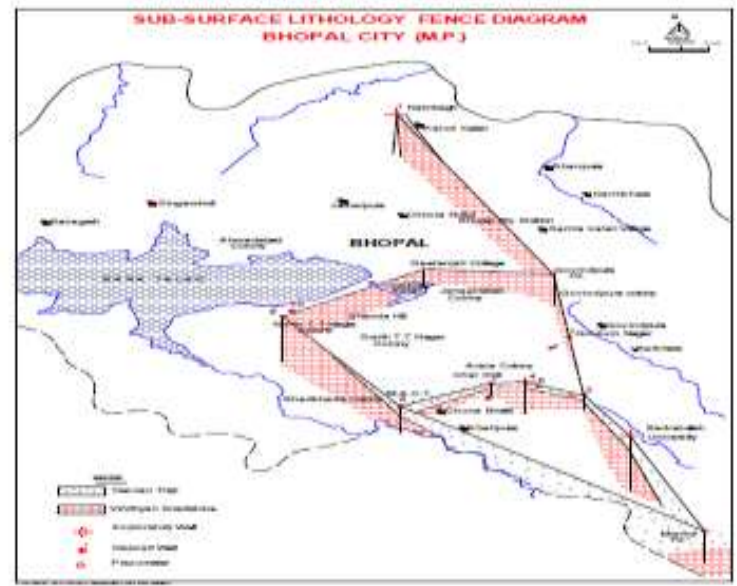

Fig 10: Hydraulic Flow Sheet

\subsubsection{Geometric properties}

For the sake of study, sample data of Bhopal area kamla park bridge (kamla park to professor colony) was taken into consideration.

Table 2: Geometric Properties of Structure

\begin{tabular}{|l|c|c|}
\hline s. no & Description & Values \\
\hline 1 & Bridge length & 30 meter \\
\hline 2 & Bridge width & 12.50 meter \\
\hline 3 & No. of lanes & Two \\
\hline 4 & Carriageway length & 6.25 meter \\
\hline 5 & Slab thickness & 2.5 meter \\
\hline 6 & Pier height & $6.5 \mathrm{~m}$ \\
\hline 7 & Size of Girder & $650 \times 800 \mathrm{~mm}$ \\
\hline 8 & Size of Pier & $1.0 \times 1.2 \mathrm{~m}$ \\
\hline 9 & Support section & Fixed \\
\hline
\end{tabular}

\subsubsection{Material properties}

In the table 3 below, description of material and their specifications are mentioned.

Table 3: Material Properties

\begin{tabular}{|c|c|c|}
\hline s. no & Description & Values \\
\hline 1 & Material property & Values \\
\hline
\end{tabular}




\begin{tabular}{|c|c|c|}
\hline 2 & Grade of concrete & $\mathrm{M}-40$ \\
\hline 3 & Young's modulus of concrete, $\mathrm{E}_{\mathrm{c}}$ & $2.17 \times 10^{4} \mathrm{~N} / \mathrm{mm}^{2}$ \\
\hline 4 & Poisson ratio & 0.17 \\
\hline 5 & Tensile Strength, Ultimate steel & $500 \mathrm{MPa}$ \\
\hline 6 & Tensile Strength, Yield steel & $250 \mathrm{MPa}$ \\
\hline 7 & Elongation at Break steel & $70 \%$ \\
\hline 8 & Foam concrete & $24.5 \mathrm{MPa}$ \\
\hline 9 & Hinges (tendons) & Fe 500 \\
\hline 10 & Jacketing tension strength & $10 \mathrm{kN}$ \\
\hline
\end{tabular}

\subsubsection{Selection of the Load Condition}

In the table 4 below, load combinations as per I.S 875-I for bridge is provided.

Table 4: Loadings and Combinations

\begin{tabular}{|l|l|l|}
\hline S. No. & Loading Type & Standard \\
\hline 1 & Dead Load & I.S. 875-I \\
\hline 2 & Live Load & I.S. 875-II \\
\hline 3 & Vehicle Load & I.R.C. 70R Class Loading \\
\hline 4 & Combination 1 & 1.5 DL + LL \\
\hline 5 & Combination 2 & 1.2 DL + LL + Vehicular load \\
\hline 6 & Combination 3 & $\begin{array}{l}0.9 \text { DL+1.2 LL+1.2 Vehicular } \\
\text { load }\end{array}$ \\
\hline
\end{tabular}

Steps for loading condition:

The load condition has to be defined as per requirement of the analysis.

As we know the model is R.C.C. structure of the bridge in which vehicle load has to be apply in different patterns. There are the different type of load has to be calculate and apply with the help of software and load are as under -Dead load -

The self load is the weight of the frame structure and any permanent load fixed there-on. The self-weight is initially assumed and checked when design is finished.

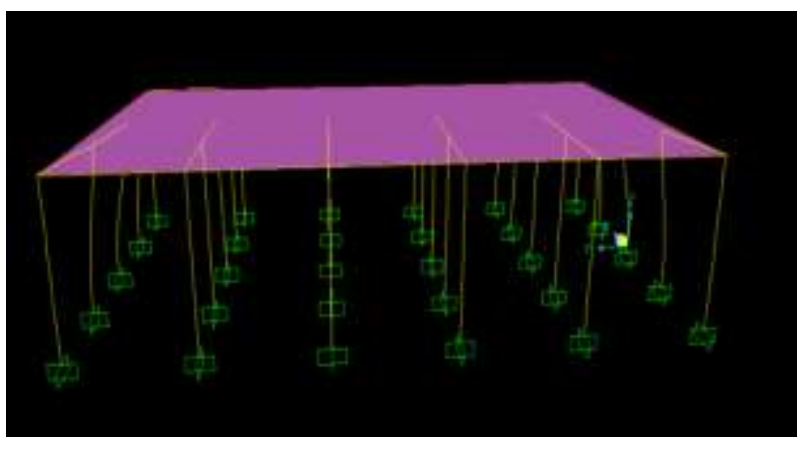

Fig 11 Dead Load

Live load -

Extension structure guidelines indicate the plan loads, which are intended to mirror the most noticeably bad stacking that can be caused on the scaffold by traffic, allowed and expected to disregard it. In India, the Highway Board indicates the standard plan loadings for extensions in scaffold rules.

For the interstate scaffolds, the Indian Road Congress has indicated standard plan loadings in IRC area II. The accompanying couple of pages brief about the loadings to be considered. For more subtleties, the peruser is alluded to the specific standard.

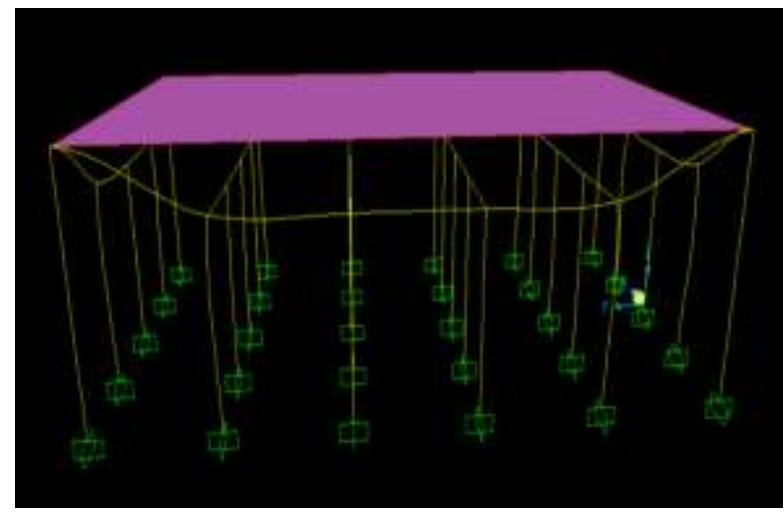

Fig 12: Live Load

In India, interstate extensions are structured as per IRC connect code. IRC: 6 - 1966 - Section II gives the determinations for the different loads and worries to be considered in scaffold structure. There are three kinds of standard loadings for which the scaffolds are structured in particular, IRC class AA stacking, IRC class A stacking and IRC class B stacking. 


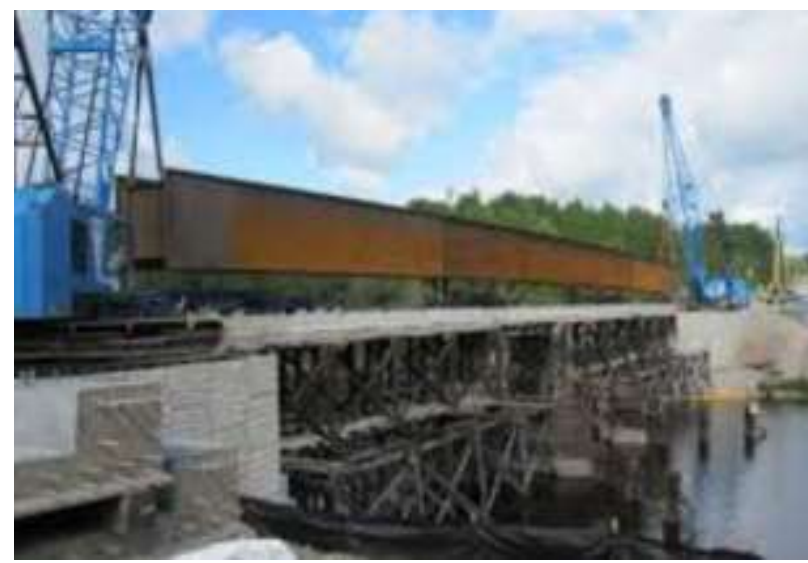

(a) Casting framework

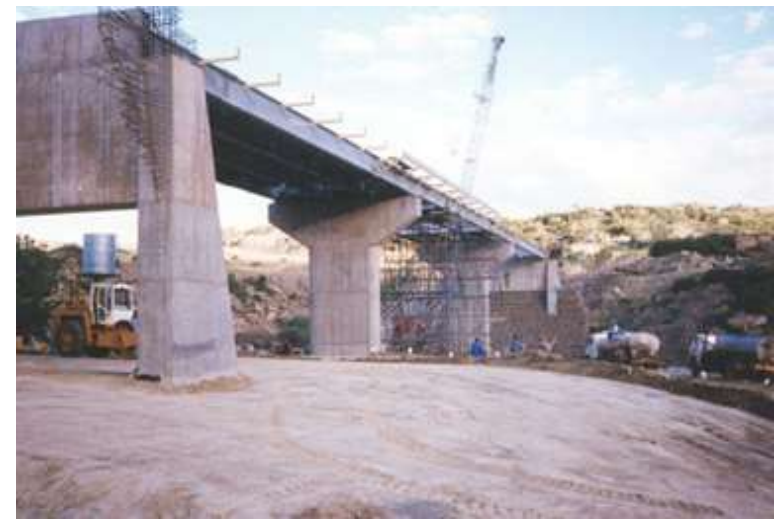

(b) Prestressing of Deck

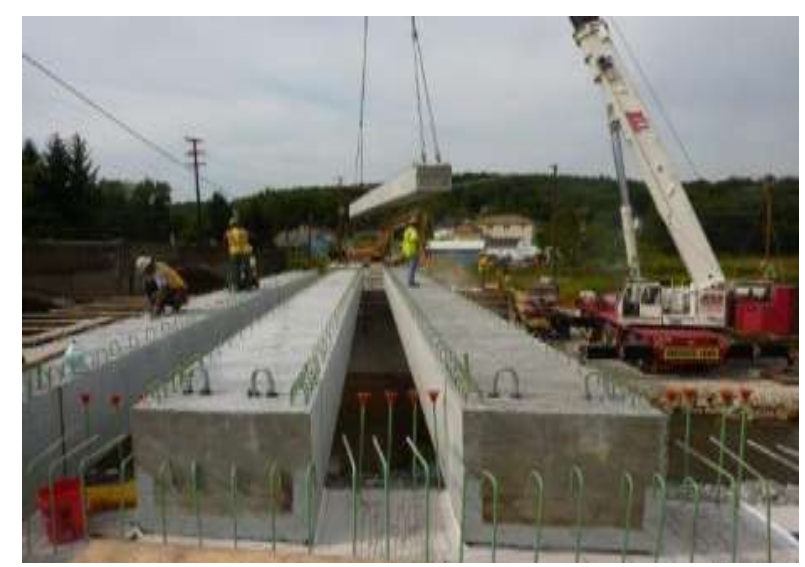

(c) Assigning Pre-stressed deck girders

Fig 13: Site working

\section{RESUlTS \& DisCUSSION}

\subsection{Finite element results}

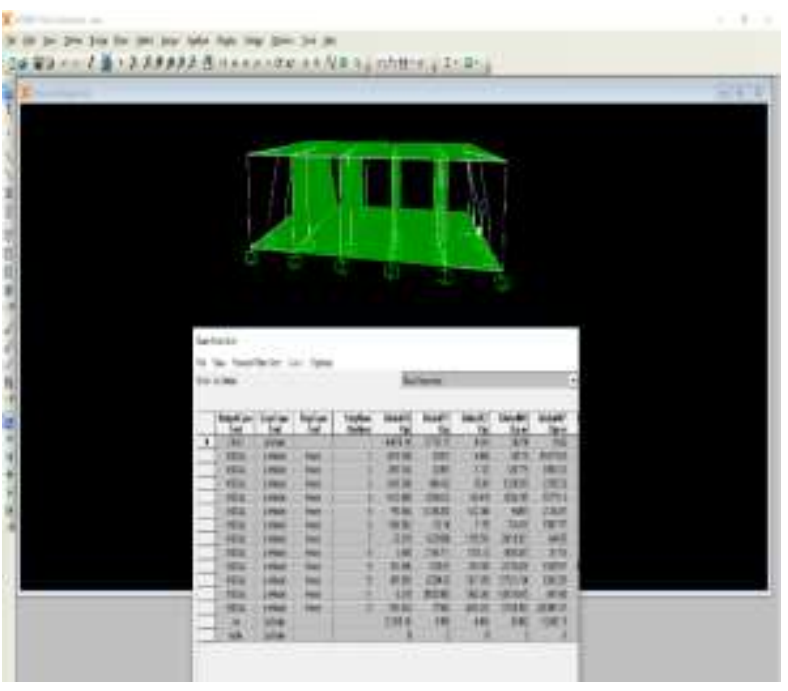

Fig 14: FEM

5.1.1 Maximum Bending Moment

Table 5: Maximum Bending Moment

\begin{tabular}{|c|c|c|c|}
\hline \multicolumn{4}{|c|}{ Max. bending moment in Pier } \\
\hline $\begin{array}{c}\text { Deck } \\
\text { Bridge } \\
\text { (RCC) }\end{array}$ & $\begin{array}{c}\text { Deck Bridge } \\
\text { (Foam } \\
\text { Concrete) }\end{array}$ & $\begin{array}{c}\text { Pre- } \\
\text { stressed } \\
\text { deck } \\
\text { bridge }\end{array}$ & $\begin{array}{c}\text { Pre-stressed deck } \\
\text { bridge (Foam } \\
\text { Concrete) }\end{array}$ \\
\hline 387.98 & 382.54 & 367.09 & 359.09 \\
\hline
\end{tabular}

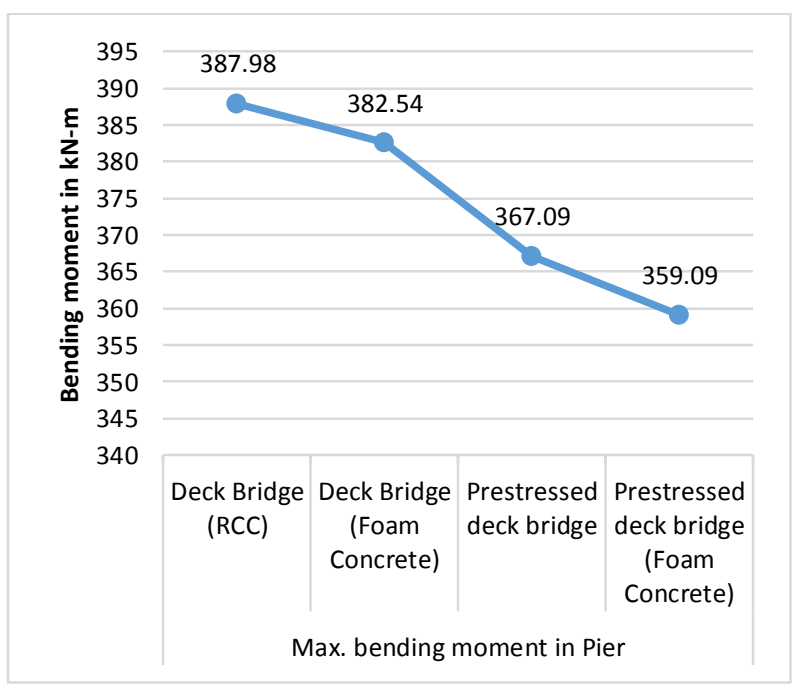

Fig 15: Maximum Bending Moment 
Inferences: It is observed in above figure that Pre-stressed foam deck bridge is observing minimum value of bending moment thus require minimum reinforcement.

\subsubsection{Maximum Shear Force}

Table 6: Maximum Shear Force

\begin{tabular}{|c|c|c|c|}
\hline \multicolumn{4}{|c|}{ Max. Shear Force in Pier } \\
\hline $\begin{array}{c}\text { Deck } \\
\text { Bridge } \\
\text { (RCC) }\end{array}$ & $\begin{array}{c}\text { Deck Bridge } \\
\text { (Foam } \\
\text { Concrete) }\end{array}$ & $\begin{array}{c}\text { Pre- } \\
\text { stressed } \\
\text { deck } \\
\text { bridge }\end{array}$ & $\begin{array}{c}\text { Pre-stressed deck } \\
\text { bridge (Foam } \\
\text { Concrete) }\end{array}$ \\
\hline 543.23 & 501.34 & 520.34 & 500.21 \\
\hline
\end{tabular}

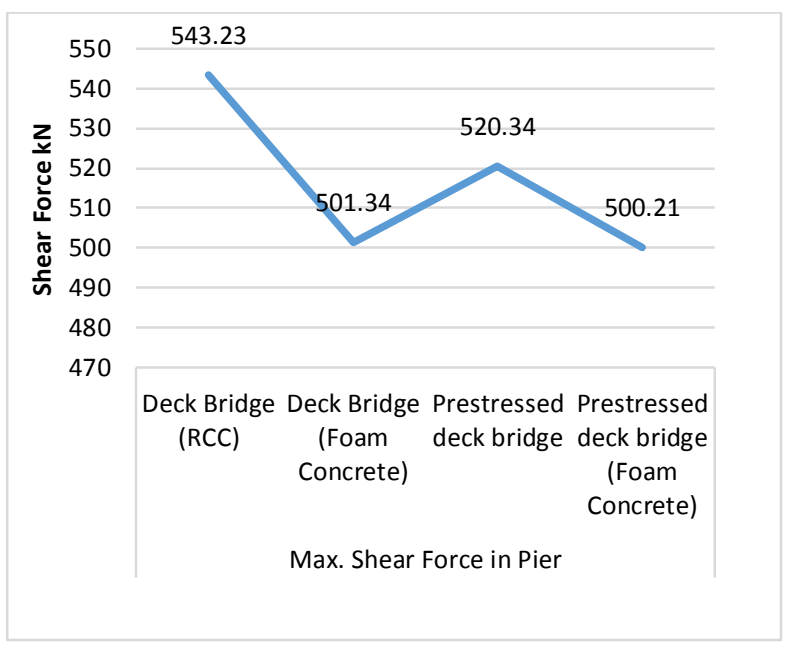

Fig 16: Shear force

Inferences: As shown in figure it is clearly observed that unbalance forces are minimum in Pre-stressed foam bridge type whereas maximum in Deck bridge R.C.C.

\subsubsection{Axial Force}

\begin{tabular}{|c|c|c|c|}
\hline \multicolumn{4}{|c|}{ Table 7: Max. Axial Force } \\
\hline $\begin{array}{c}\text { Deck } \\
\text { Bridge } \\
\text { (RCC) }\end{array}$ & $\begin{array}{c}\text { Deck Bridge } \\
\text { (Foam } \\
\text { Concrete) }\end{array}$ & $\begin{array}{c}\text { Pre- } \\
\text { stressed } \\
\text { deck } \\
\text { bridge }\end{array}$ & $\begin{array}{c}\text { Pre-stressed deck } \\
\text { bridge (Foam } \\
\text { Concrete) }\end{array}$ \\
\hline 2033.09 & 1896.38 & 1804.45 & 1609.65 \\
\hline
\end{tabular}

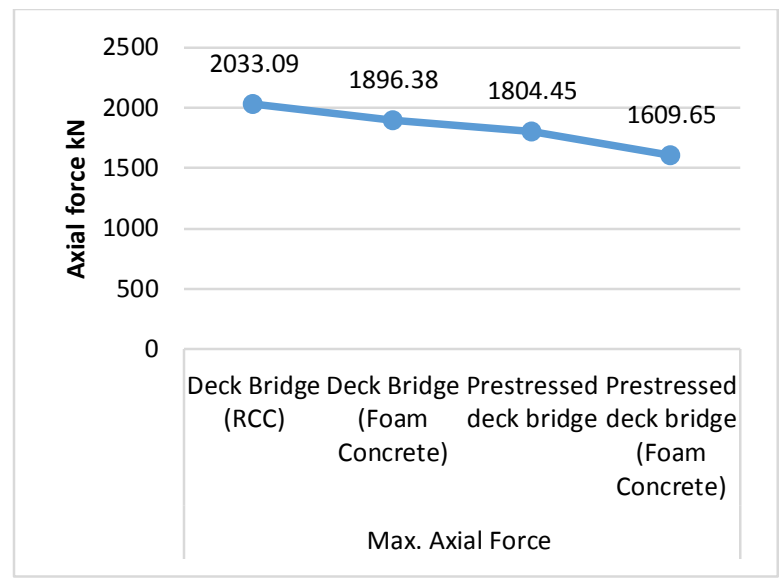

Fig 17: Axial force

Inferences: Here it is clearly observed that Vertical forces are distributed uniformly in Pre-stressed deck bridge (foam) whereas worst in Deck bridge R.C.C. case.

\subsubsection{Maximum Deflection}

\begin{tabular}{|c|c|c|c|}
\hline \multicolumn{4}{|c|}{ Table 8: Deflection } \\
\hline $\begin{array}{c}\text { Deck } \\
\text { Bridge } \\
\text { (RCC) }\end{array}$ & $\begin{array}{c}\text { Deck Bridge } \\
\text { (Foam } \\
\text { Concrete) }\end{array}$ & $\begin{array}{c}\text { Pre- } \\
\text { stressed } \\
\text { deck } \\
\text { bridge }\end{array}$ & $\begin{array}{c}\text { Pre-stressed } \\
\text { deck bridge } \\
\text { (Foam Concrete) }\end{array}$ \\
\hline 25.67 & 24.34 & 20.09 & 16.54 \\
\hline
\end{tabular}

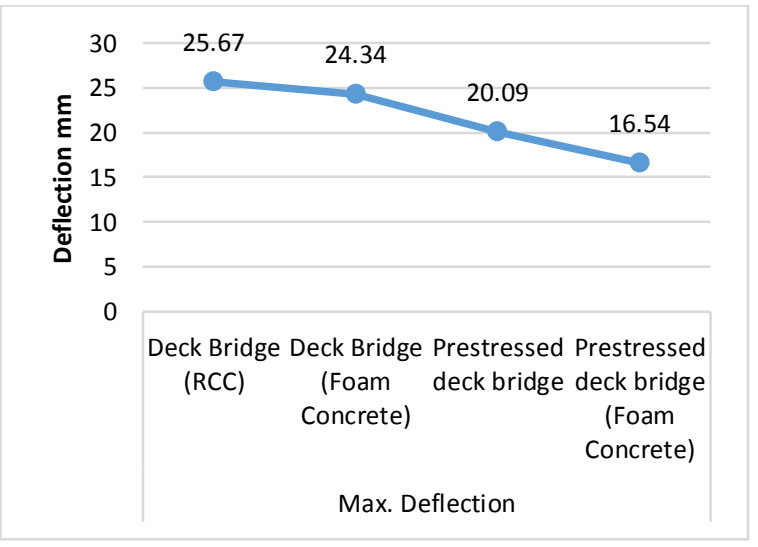

Fig 18: Axial force

Inferences: Here result shows that due to the effect of pretensioning member deflection is minimum in Pre-stressed cases also due to introduction of foam concrete it is further improved. 
5.2 Deck analysis

Table 9: Reactions at Node of RCC deck type bridge

\begin{tabular}{|c|c|c|c|c|c|c|}
\hline Output Case & Global FX & Global FY & Global FZ & Global MX & $\begin{array}{c}\text { Global } \\
\text { MY }\end{array}$ & Global MZ \\
\hline Unit & KN & KN & KN & KN & KN-m & KN-m \\
\hline NODAL & 122.54 & 26.56 & 8.7607 & -15.123 & 2.45 & 44.45 \\
\hline NODAL & 119.05 & 27.09 & 0.033 & -17.54 & 2.87 & 38.09 \\
\hline NODAL & 115.56 & 28.09 & -1.5491 & 28.65 & 3.29 & 26.61 \\
\hline NODAL & 112.07 & 24.98 & -9.561 & 54.357 & 3.71 & 24.56 \\
\hline NODAL & 108.58 & 21.87 & -339.06 & 25.7 & 4.13 & 22.51 \\
\hline NODAL & 105.09 & 18.76 & 2.082 & -12.54 & 4.55 & 20.46 \\
\hline NODAL & 101.6 & 15.65 & -0.011 & 18.34 & 4.97 & 18.41 \\
\hline NODAL & 98.11 & 12.54 & 1742.26 & 13.2 & 5.39 & 16.36 \\
\hline NODAL & 94.62 & 10.45 & -34.765 & -26.87 & 5.81 & 14.31 \\
\hline NODAL & 91.13 & 9.45 & -279 & -20.98 & 6.23 & 12.26 \\
\hline NODAL & 87.64 & 8.45 & 0.00178 & 43.33 & 6.65 & 10.21 \\
\hline NODAL & 84.15 & 7.45 & -59621 & -44.32 & 7.07 & 8.16 \\
\hline
\end{tabular}

Table 10: Reactions at Node of Foam Concrete deck type bridge

\begin{tabular}{|c|c|c|c|c|c|c|}
\hline Output Case & Global FX & Global FY & Global FZ & Global MX & Global MY & Global MZ \\
\hline Unit & KN & KN & KN & KN & KN-m & KN-m \\
\hline NODAL & 102.76 & 27.97 & 8.7607 & 15.123 & 3.2006 & 36.066 \\
\hline NODAL & 112.54 & 22.65 & 0.033 & -17.54 & 3.56 & 33.55 \\
\hline NODAL & 121.8 & 17.33 & -1.5491 & 28.65 & 3.9194 & 42.34 \\
\hline NODAL & 116.98 & 12.01 & -9.561 & 54.357 & 4.2788 & 32.05 \\
\hline NODAL & 122.4 & 26.54 & -339.06 & 25.7 & 4.6382 & 39.09 \\
\hline NODAL & 112.43 & 24.43 & 2.082 & -12.54 & 4.9976 & 32 \\
\hline NODAL & 109.76 & 22.32 & -0.011 & 18.34 & 5.357 & 24.91 \\
\hline NODAL & 107.09 & 20.21 & 1742.26 & 13.2 & 5.7164 & 17.82 \\
\hline
\end{tabular}




\begin{tabular}{|c|c|c|c|c|c|c|} 
NODAL & 104.42 & 18.1 & -34.765 & -26.87 & 6.0758 & 10.73 \\
\hline NODAL & 101.75 & 15.99 & -279 & -20.98 & 6.4352 & 14.99 \\
\hline NODAL & 99.08 & 13.88 & 0.00178 & 43.33 & 6.7946 & 13.87 \\
\hline NODAL & 96.41 & 11.77 & -59621 & -44.32 & 7.154 & 20.07 \\
\hline
\end{tabular}

Table 11: Reactions at Node of RCC (Pre-stressed) deck type bridge

\begin{tabular}{|c|c|c|c|c|c|c|}
\hline Output Case & Global FX & Global FY & Global FZ & Global MX & Global MY & Global MZ \\
\hline Unit & KN & KN & KN & KN & KN-m & KN-m \\
\hline NODAL & 20.04 & 21.54 & 9.07 & -15.123 & 3.2006 & 22.32 \\
\hline NODAL & 19.05 & 25.06 & -4.54 & -17.54 & 3.56 & 21.09 \\
\hline NODAL & 118.75 & 22.05 & 1.65 & 28.65 & 3.9194 & 19.86 \\
\hline NODAL & 102.354 & 19.04 & 9.765 & 54.357 & 4.2788 & 18.63 \\
\hline NODAL & 85.958 & 16.03 & -7.87 & 25.7 & 4.6382 & 17.4 \\
\hline NODAL & 69.562 & 13.02 & 2.082 & -12.54 & 4.9976 & 16.17 \\
\hline NODAL & 53.166 & 10.01 & -0.011 & 18.34 & 5.357 & 14.94 \\
\hline NODAL & 66.43 & 13.54 & 10.09 & 13.2 & 5.7164 & 18.09 \\
\hline NODAL & 63.23 & 17.07 & -21.07 & -26.87 & 6.0758 & 41.56 \\
\hline NODAL & 75.65 & 20.6 & -2.08 & -20.98 & 6.4352 & 40.87 \\
\hline NODAL & 88.095 & 14.55 & 0.56 & 43.33 & 6.7946 & 38.66 \\
\hline NODAL & 90.66 & 18.76 & -5.76 & -44.32 & 7.154 & 3.23 \\
\hline
\end{tabular}

Table 12: Reactions at Node of Foam concrete (Pre-stressed) deck type bridge

\begin{tabular}{|c|c|c|c|c|c|c|}
\hline Output Case & Global FX & Global FY & Global FZ & Global MX & Global MY & Global MZ \\
\hline Unit & KN & KN & KN & KN & KN-m & KN-m \\
\hline NODAL & 119.76 & 25.05 & 8.7607 & -15.123 & 2.45 & 40.66 \\
\hline NODAL & 116 & 26.44 & 0.033 & -17.54 & 2.87 & 42.1 \\
\hline NODAL & 120.02 & 22.65 & -1.5491 & 28.65 & 3.29 & 37.65 \\
\hline NODAL & 116.87 & 18.86 & -9.561 & 54.357 & 3.71 & 33.2 \\
\hline NODAL & 112.05 & 15.07 & -339.06 & 25.7 & 4.13 & 28.75 \\
\hline NODAL & 107.23 & 11.28 & 2.082 & -12.54 & 4.55 & 24.3 \\
\hline NODAL & 102.41 & 15.65 & -0.011 & 18.34 & 4.97 & 19.85 \\
\hline NODAL & 97.59 & 13.76 & 1742.26 & 13.2 & 5.39 & 15.4 \\
\hline NODAL & 92.77 & 20.05 & -34.765 & -26.87 & 5.81 & 14.31 \\
\hline NODAL & 87.95 & 21.76 & -279 & -20.98 & 6.23 & 12.26 \\
\hline
\end{tabular}




\begin{tabular}{|c|c|c|c|c|c|c|} 
NODAL & 83.13 & 19.876 & 0.00178 & 43.33 & 6.65 & 10.21 \\
\hline NODAL & 78.31 & 18.87 & -59621 & -44.32 & 7.07 & 8.16 \\
\hline
\end{tabular}

Table 13: Deck analysis for different parameters (Top Deck Slab)

\begin{tabular}{|c|c|c|c|c|}
\hline Parameters & Deck Bridge (RCC) & $\begin{array}{c}\text { Deck Bridge (Foam } \\
\text { Concrete) }\end{array}$ & $\begin{array}{c}\text { Pre-stressed deck } \\
\text { bridge }\end{array}$ & $\begin{array}{c}\text { Pre-stressed deck bridge } \\
\text { (Foam Concrete) }\end{array}$ \\
\hline B.M. (KN-m) & 44.45 & 42.34 & 42.1 & 21.56 \\
\hline S.F. (KN) & 28.09 & 27.97 & 26.44 & 118.75 \\
\hline A.F. (KN) & 122.54 & 122.4 & 120.02 & 40.15 \\
\hline Deflection (mm) & 45.65 & 44.34 & 42.35 & \\
\hline
\end{tabular}

\subsection{Economic Analysis}

Table 14: Economic Analysis

\begin{tabular}{|c|c|c|c|c|c|c|}
\hline Type & $\begin{array}{c}\text { concrete } \\
(\text { cu.m) }\end{array}$ & $\begin{array}{c}\text { Rebar } \\
(\mathrm{kg})\end{array}$ & $\begin{array}{c}\text { S.O.R. rate } \\
\text { concrete }\end{array}$ & $\begin{array}{c}\text { S.O.R. rate } \\
\text { rebar }\end{array}$ & $\begin{array}{c}\text { total } \\
\text { concrete }\end{array}$ & total rebar \\
\hline Deck Bridge (RCC) & 352.75 & 2215.05 & 4500 & 56 & 1587375 & 124042.8 \\
\hline $\begin{array}{c}\text { Deck Bridge (Foam } \\
\text { Concrete) }\end{array}$ & 302.98 & 2096.45 & 4500 & 56 & 1363410 & 117401.2 \\
\hline $\begin{array}{c}\text { Pre-stressed deck } \\
\text { bridge }\end{array}$ & 290.76 & 2103 & 4500 & 56 & 1308420 & 117768 \\
\hline $\begin{array}{c}\text { Pre-stressed deck } \\
\text { bridge (Foam } \\
\text { Concrete) }\end{array}$ & 220.76 & 1800 & 4500 & 56 & 993420 & 100800 \\
\hline
\end{tabular}

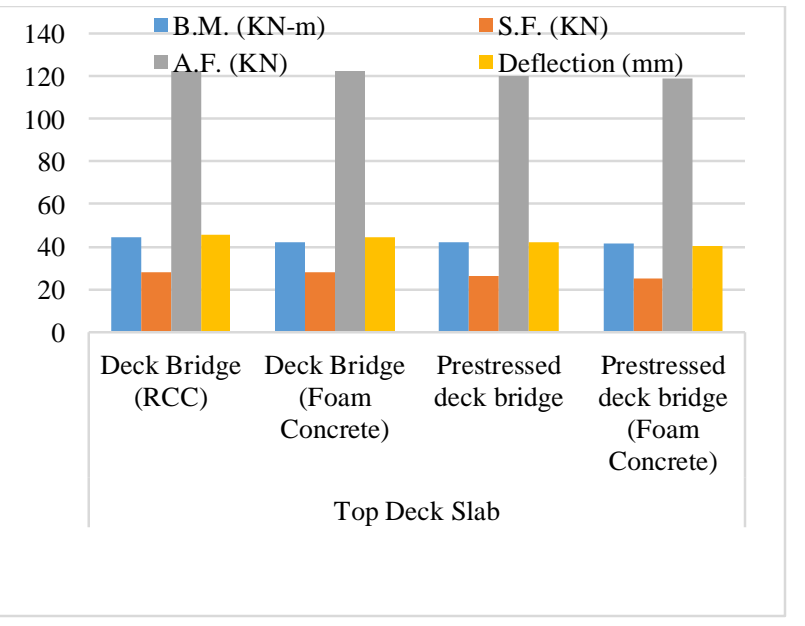

Fig 19: Deck analysis
Summarized Results:

As per quantity analysis and cost estimation using S.O.R. 2020, it is determined that Pre-stressed deck type bridge using foam concrete is comparatively best in terms of resisting forces and cost economical. Whereas Deck type R.C.C. bridge shows worst result.

\section{CONCLUSIONS}

Findings of the project can be concluded as below:

- In this comparative analysis it is clearly stated that Prestressed bridge (Foam concrete) is more stable in resisting load. 
- In this study Hydraulic calculation is determined using topography sheet available as per Indian standard using dickens formulae.

- In this study we manually calculate the total discharge and assigned it in software.

- It is concluded that in terms of cost Deck type bridge R.C.C. is comparatively more costlier than Pre-stressed bridge.

- I.R.C. loading is applied for justification of vehicular load analysis.

\section{VII.FUTURE SCOPE}

Following future aspects can be consider are as follows:

- Cable suspension bridge or any other type can be consider.

- Seismic analysis can be proceed.

- $\quad$ AASHTO specification can be preferred instead of I.R.C.

- Midas Bridge designer can be used for analysis in future.

\section{REFERENCES}

[1] Gaurav Somani, "A Comparative Study on T Girder Bridge Deck using Grillage Analogy and Finite Element Method", international journal of engineering research \& technology (IJERT), Volume 10, Issue 06 (June 2021).

[2] K. Hemalatha, Chippymol James, L. Natrayan "Analysis of RCC T-beam and prestressed concrete box girder bridgessuper structure under different span conditions", Materials Today, 2 July 2020.

[3] Meghana K V, G V Sowjanya "Review Paper on Comparative Analysis of T-Beam Bridge and Box Girder Bridge", International Journal of Engineering Research \& Technology (IJERT), Special Issue - 2020.

[4] Manohar R, B Suresh Chandra "Finite Element Analysis of slabs, cross girders and main girders in RC T-Beam Deck Slab Bridge", International Research Journal of Engineering and Technology (IRJET), Vol 5, Issue 08, 2018.

[5] Tangupalli Mahesh Kumar and J Sudhamani, "Analysis of T-Beam Deck Slab Bridge in Different Methods",International Journal for Technological Research in Engineering, (IJTRE), Vol 4, Issue 12,Aug 2017.

[6] Abrar Ahmed, Prof. R.B. Lokhande "Comparative Analysis and Design of T-beam and box girders", International Research Journal of Engineering and Technology (IRJET), Vol 4, July 2017.

[7] Y YaduPriya and T Sujatha, "Comparative Analysis of Post Tensioned T-Beam Bridge Deck by Rational Method and Finite Element Method", International Journal of Research in IT, Management and Engineering, Vol 6, Issuue 7, Sept 2016.

[8] OmkarVelhal, J.P. Patankar "Study of R.C.C. T-Beam Bridge with Skew Angle", International Journal of Innovative Research in Science, Engineering and Technology, Vol. 5, Issue 6, June 2016. 